\title{
„Kto garstką ziemię nosi, góry się doczeka" - problematyka wychowawcza na łamach czasopisma „Zorza. Dziennik młodemu wiekowi poświęcony" Pauliny Krakowowej i Walentyny Trojanowskiej
}

Historia czasopiśmiennictwa dla dzieci w Królestwie Polskim sięga czasów przed powstaniem listopadowym, kiedy w 1824 r. Klementyna z Tańskich Hoffmanowa wydała „Rozrywki dla Dzieci” - pierwsze oryginalne czasopismo adresowane do młodych czytelników. Pismo wychodziło co miesiąc przez pięć lat - do 1828 roku, cieszyło się bardzo dużą poczytnością, swym zasięgiem obejmowało wszystkie ziemie polskie ${ }^{1}$. Autorka Pamiątki po dobrej matce podjętą inicjatywą wypełniła lukę na rynku wydawniczym i uświadomiła wydawcom potrzebę istnienia czasopisma dedykowanego dzieciom i młodzieży. W ślady Hoffmanowej poszedł Ignacy Kajetan Chrzanowski i już w styczniu 1829 r. na półki księgarń trafił „Tygodnik dla Dzieci”, redagowany we współpracy ze Stanisławem Jachowiczem². Gdy „Tygodnik dla Dzieci” przestał wychodzić, w 1830 r. jego miejsce zajął „Dziennik dla Dzieci” - pierwszy nie tylko na ziemiach polskich, ale i w Europie periodyk codzienny przeznaczony dla dziecięcego odbiorcy ${ }^{3}$. Redaktorem naczelnym został Stanisław Jachowicz, w skład redakcji wchodził też Ignacy Kajetan Chrzanowski. W 1830 r. z myślą o dzieciach wydawano także dwutygodnik „Ziemomysł. Pismo czasowe dla dzieci” Jana Kantego Chruckiego oraz miesięcznik „Skarbiec dla Dzieci” Leona i Karola Sienkiewiczów ${ }^{4}$ Represje popowstaniowe

* Dr.

1 I. Kaniowska-Lewańska, Literatura dla dzieci i młodzieży do roku 1864, Warszawa 1980, s. $115-121$.

2 Tamże, s. 122-123.

3 L. Żarów-Mańszewska, „Dziennik dla Dzieci” Stanisława Jachowicza, „Rozprawy z Dziejów Oświaty" 1961, red. J. Miąso, t. IV, s. 125-176.

4 I. Kaniowska-Lewańska, Literatura dla dzieci młodzieży..., s. 129-133. 
zahamowały rozwój prasy dziecięcej i dopiero w latach 1835-1836 na rynku pojawił się periodyk miesięczny "Magazyn dla Dzieci. Dziennik użytecznych i przyjemnych wiadomości” pod redakcją Leona Rogalskiego. „Magazyn dla Dzieci” wychodził jako dodatek do czasopisma dla dorosłych - „Magazynu Powszechnego". Wydawany przez firmę Glücksbergów, reprezentujących poglądy lojalistyczne i zachowawcze, miesięcznik nie nabrał oblicza narodowego, bogato ilustrowany, wzorowany na zachodnich magazynach, nosił wyłącznie encyklopedyczny charakter ${ }^{5}$. Po kilku latach przerwy władze zezwoliły na druk nowego pisma dla dzieci i młodzieży, tym razem „Zorzy” ukazującej się w Warszawie od 1843 r. w formie dwutygodnika i mniej regularnie w $1844 \mathrm{r}^{6}{ }^{6}$ „Zorza. Dziennik młodemu wiekowi poświęcony” wzorował się na tak lubianych przez małoletnich czytelników „Rozrywkach..." Hoffmanowej. Podobnie jak autorce „Rozrywek” przyświecał światły zamysł wyartykułowany we wstępie Do dzieci: „Być wam użyteczną, nauczać was i zabawiać, dopomagać ile w mojej mocy do rozkrzewienia w sercach waszych czystej miłości cnoty”, tak i redakcja "Zorzy” postawiła przed sobą szczytny cel wychowawczy i moralizatorski. Redagowania pisma podjęły się Paulina z Radziejewskich Krakowowa (1813-1882) i Walentyna Trojanowska (1817-1891). Krakowowa znana była już wówczas jako redaktorka pierwszego literackiego magazynu dla kobiet „Pierwiosnek” (1838-1843) oraz autorka opartej na motywach autobiograficznych powieści Pamiętniki młodej sieroty (1839 r.) ${ }^{8}$, Trojanowska - nauczycielka na warszawskiej pensji - dała się poznać jako poetka, jej utwory poetyckie drukowano na łamach czasopism, m.in. „Kłosów”, „Ogniska Domowego”, „Przyjaciela Ludu”, „Przeglądu Naukowego”. „Zorzę” wydawano w Drukarni Maksymiliana Chmielewskiego (1804-1851), mieszczącej się przy ulicy Senatorskiej 463 w Warszawie. Pod szyldem wydawnictwa Chmielewskiego wychodziły wcześniej dla przykładu: ilustrowany tygodnik, od 1838 r. miesięcznik „Muzeum Domowe. Dzieło poświęcone historyi, statystyce, moralności, naukom i literaturze krajowej” (1835-1839) Franciszka Salezego Dmochowskiego, „Pierwiosnek” Krakowowej, miesięcznik „Przegląd Warszawski Literatury, Historyi, Statystyki i Rozmaitości” (1840-1842) Jakuba Budziłowicza i Hipolita Skimborowicza, „Przegląd Naukowy, Literaturze, Wiedzy i Umnictwu Poświęcony" (1842-1848) pod redakcją Skimborowicza. Skład główny „Dziennika” mieścił się w Księgarni Gustawa Adolfa Sennewalda przy ulicy Miodowej. Redakcji „Zorzy” udało się koncepcją wydawania czasopisma poświęconego „młodemu wiekowi” zainteresować liczne grono autorów i zachęcić ich do współpracy. Na kartach pisma, obok większości artykułów i wierszy, które wyszły spod pióra Pauliny Krakowowej i Walentyny Trojanowskiej, odnajdziemy m.in. teksty autorstwa Stanisława Jachowicza, Teofila

5 Tamże, s. 137-141.

6 W połowie 1844 r. Walentyna Trojanowska, możliwe że ze względów bezpieczeństwa, przeniosła się do Galicji, w tej sytuacji Krakowowa zdecydowała o zamknięciu pisma. Tamże, s. 141-144.; Słownik literatury dziecięcej i młodzieżowej, red. G. Leszczyński, B. Tylicka, Wrocław 2002, s. 428.

7 Cyt. za I. Kaniowska-Lewańska, Literatura dla dzieci i młodzieży..., s. 117.

8 I. Kaniowska-Lewańska, Krakowowa z Radziejewskich Petronela Paulina, [w:] Polski Słownik Biograficzny, Wrocław-Warszawa 1970, t. XV, red. E. Rostworowski, s. 123-125.

9 http://www.niecodziennik.mbp.lublin.pl/index.php?option=com_content\&task=view\&id=909\&ltemid $=358$. 
Nowosielskiego, Edwarda Bogusławskiego, Władysława Miniewskiego, Ignacego Dobrskiego, Szymona Zajączkowskiego, księdza Pawła Rzewuskiego, Józefy Prusieckiej, Emilii Płużańskiej, Pauliny Wilkońskiej i Tekli Łubieńskiej. „Zorzę” wyróżniała staranna szata graficzna i wyrazisty druk. Na każdy numer składały się „proza” i „wiersze”, co do tematyki - zamieszczano fabularne opowiadania, powiastki moralistyczne, komedyjki, materiały biograficzne, historyczne, historycznoliterackie, przyrodnicze, opisy podróży. Adresatami periodyku były dzieci i młodzież w Królestwie Polskim mające utrudniony dostęp do szkolnictwa pod rządami namiestnika Iwana Paskiewicza. Niewygórowana cena czyniła periodyk ogólnodostępnym. We wstępie otwierającym pierwszy numer pisma redaktorki sformułowały jego program ideowy, zapowiadały artykuły „oparte na religii chrześcijańskiej, moralność głoszące, i przykładami cnoty zachęcające do jej pełnienia"10. Już na karcie tytułowej z rozmysłem umieszczono złote myśli Kazimierza Brodzińskiego: „Kto garstką ziemię nosi, góry się doczeka”, „Czyń każdy w swojem kółku co każe duch boży, A całość sama się ułoży".

„Zorza” na bieżąco informowała własne grono czytelnicze - dzieci wraz z rodzicami - o godnych polecenia nowościach wydawniczych. Już w pierwszym tomie zachęcała do lektury nowego pisma „Motyl” poświęconego naukom przyrodniczym, którego redaktorem i autorem większości artykułów był nauczyciel gimnazjum, autor prac z dziedziny fizyki - Józef Żochowski ${ }^{11}$. Rekomendowała również książkę „ku zabawie i nauce dzieci” - Świat dziecięcy autorstwa Teofila Nowosielskiego - czterotomowe dziełko drukowane w 1842 r. oraz wydane w 1843 r. Powieści moralne dla młodzieży przełożone z języka francuskiego przez Józefa Kazimierza Skibińskiego ${ }^{12}$. Co do ostatniej $z$ wymienionych pozycji Paulina Krakowowa podkreślała, że o jej wartości stanowiła nie tylko zajmująca narracja, ale wierny przekład z francuskiego sprawiający, że „książeczka ta bardzo korzystną stać się może, dla pragnących

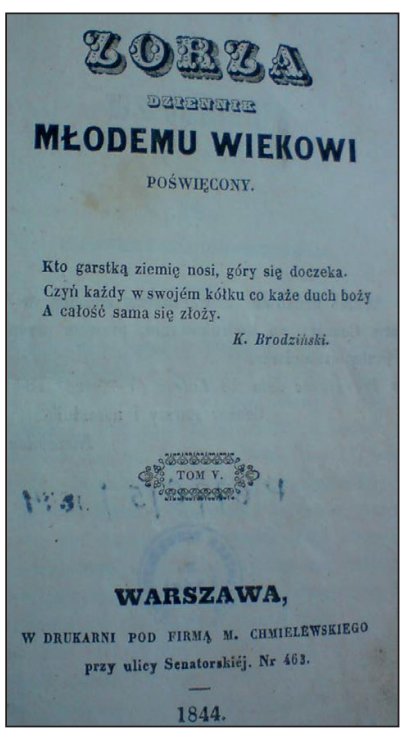
wprawić się w tłumaczenie"13. Walentyna Trojanow-

ska na łamach czwartego tomu spodziewała się, że dzieci „wdzięcznym sercem” przyjmą Powieści moralne Józefy Prusieckiej i "ugruntują w duszy” głoszoną przez nie moralność ${ }^{14}$. W tomie piątym z 1844 r. podano wiadomość o wyjściu w druku następujących pozycji: Historii polskiej Michała Balińskiego, Deklamatora polskiego - zbioru utworów literatury krajowej zebranego przez Fryderyka Henryka Lawestama oraz jego powieści w podtytule przeznaczonej dla grzecznych

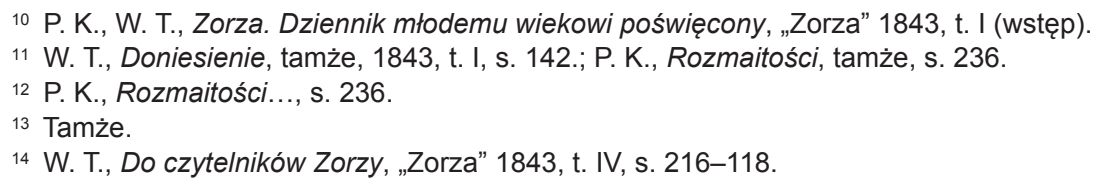


dzieci Obrazki z pożycia dobrej rodziny. Donoszono także o drugiej edycji Pamiętników młodej sieroty pióra redaktorki „Zorzy” Pauliny Krakowowej i Niespodziance: zbiorze powiastek dla małych dzieci autorstwa tejże ${ }^{15}$. Jako pożyteczną lekturę dla starszych dziewcząt Walentyna Trojanowska wskazywała wyselekcjonowane przez matkę lub nauczycielkę fragmenty dziełka Klementyny z Tańskich Hoffmanowej Święte niewiasty: obrazki pobożne kobietom żyjącym w świecie ofiarowane, recenzowała: „wzory piękne do naśladowania, styl ujmujący czystą polszczyzną i wdziękiem. Ale dzieło to sama autorka pisała dla dorosłych, a młodzi czytelnicy czytać mogą tylko wskazane miejsca, wybrane żywota”16. Redakcja „Zorzy” zapraszała dziatwę do sięgania po przeznaczone dla niej książki i czasopisma, nie pomijała też jakże ważnej kwestii uczestnictwa młodzieży w życiu kulturalnym miasta, stąd anons koncertów sławnego Franciszka Liszta i rokującego wielką przyszłość dwunastoletniego Antoniego Rubinsteina ${ }^{17}$.

Przywołując znów zaczerpnięte od Brodzińskiego motto „Zorzy”: „Kto garstką ziemię nosi, góry się doczeka" - przejdźmy do omówienia cnót - metaforycznie ujmując ziarenek ziemi, wedle redaktorek i autorów niniejszego pisma, składających się na górę, to jest moralność człowieka.

\section{Niekłamana pobożność}

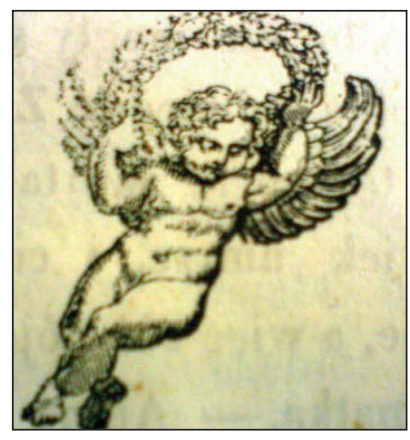

By uczynić cnotę pobożności bliższą dziecięcemu sercu, zamiast wyobrażenia Boga - surowego Sędziego karzącego każdy zły uczynek, konsekwentnie prezentowano na łamach „Zorzy” wizerunek łaskawego Ojca, zatroskanego o dobro maluczkich, czuwającego nieznużenie nad dolą człowieka. Tym sposobem stosunek dziecka wobec Boga w miejsce bojaźni i strachu budowano na miłości, wdzięczności, nadziei. Wpajano młodym czytelnikom przekonanie, że we wszystkich momentach życia należy zwracać się do Boga - dziękować w chwilach radości, a w trudnych rozterkach u Niego szukać ratunku. Mały Leoś - bohater powiastki Pomoc i pociecha, nie radził sobie z opanowaniem zadanej lekcji, bezskutecznie próbował utrwalić w pamięci książkową wiedzę, zakłopotany, zawstydzony, obawiał się krytyki rodziców i nauczyciela. Dopiero przykład sędziwego staruszka, który na klęczkach u stóp krzyża wyglądał pocieszenia po stracie życiowego dobytku strawionego pożarem, po śmierci ukochanej żony i jedynego syna, wywarł na chłopcu niezatarte wrażenie, uzmysłowił, jak wielką otuchę wlewa w udręczone serce żarliwa modlitwa. Leoś w swym nieporównanie drobniejszym

\footnotetext{
15 Taż, Doniesienia, tamże, 1844, t. V, s. 166-168.

16 Tamże.

17 P. K., Rozmaitości..., s. 237.
} 
zmartwieniu ukląkł przy ukrzyżowanym Chrystusie, by prosić o tak potrzebną w nauce wytrwałość. Ufny w Bożą pomoc przezwyciężył trudności, przygotował lekcję i odtąd już każdy dzień rozpoczynał modlitwą. „Kochane dzieci trzeba się modlić szczerze, trzeba ażeby to co wymawiają wasze usta, powtórzyło i serce, i żebyście ufały w dobroci Boga" - tymi słowami puentował powiastkę Edward Bogusławski ${ }^{18}$. O potrzebie modlitwy wielokrotnie pisano w „Zorzy”, przekonywano dzieci, że tylko w Bogu godzi się pokładać nadzieję, tylko Jemu w modlitewnym błaganiu powierzać swoje tęsknoty, gdyż to On jest Najwyższy, Wszechmocny, jest Stwórcą całego świata i tak jak zliczone przez Niego są wszystkie gwiazdy, jak w Jego opiece znajduje się najmniejszy robaczek, rybka w wodzie i piasek w morzu, tak Bóg nie zapomni nigdy o wzywającej Jego miłosierdzia dziecinie.
„Czy wiesz ile dziatek
Z łóżeczek powstaje,
I w tkliwych modlitwach
Bogu cześć oddaje?
O! Bóg je policzył,
Ty staniesz w ich rzędzie,
Jeśli twe serduszko
Wielbić Boga będzie" - dowodził Stanisław Jachowicz ${ }^{19}$.

W wierszu Zorza. Święte budzi uczucia Jachowicz ukazał ubogich rodziców siedmiorga dziatek, którzy mimo doskwierającego niedostatku o poranku składali Bogu korne dzięki i powierzali Jego pieczy śpiące w blasku zorzy potomstwo, głęboko wierząc, że „kto sen daje i piękną zorzę, ten i dziateczki wyżywić może”20. Z polecenia Boga każdemu bez wyjątku od dnia narodzin towarzyszył przecież Anioł Stróż, o czym przypominali czytelnikom w pięknych wierszach m.in. Teofil Nowosielski ${ }^{21}$ i Walentyna Trojanowska - sięgający po motyw aniołka radującego się z czynionych przez dzieci dobrych uczynków, na odwrót zasmuconego, gdy dzieci dopuszczały się grzechu:

„O! pomnij dziecino miła!

Abyś w każdej dobie

Uśmiech aniołka wzbudziła

Aby sprzyjał tobie"22.

Mała Ludwisia w opowiadaniu Strach bała się ciemności, nieoświetlony pokój przejmował ją trwogą, powodował szybsze bicie serca, a pobudzona wyobraźnia poddawała wizje zjaw czających się w mroku. Dziewczynka wyzbyła się lęku,

18 E. Bogusławski, Pomoc i pociecha, „Zorza” 1843, t. II, s. 84-88.

19 S. Jachowicz, Do dziecięcia, tamże, 1843, s. 129-130.

20 Tenże, Zorza. Święte budzi uczucia, tamże, 1843, t. I, s. 47-48.

21 T. Nowosielski, Anioł w dzień twych urodzin, tamże, 1844, t. V, s. 260-261.

22 W. T., Do małej dziewczynki, tamże, 1843, t. IV, s. 41-42. 
kiedy dowiedziała się od mamy, że w każdej chwili strzeże jej aniołek wysłany od Boga i w żadnym razie nie pozwoli, aby w ciemnym pokoju przytrafiło się jej coś złego ${ }^{23}$.

Autorzy związani z pismem kierowali uwagę dzieci w stronę Boga i aniołów, ale nie zapominali też o ziemskich apostołach Bożej miłości - członkach zgromadzeń zakonnych czy o wyniesionych na ołtarze. Niejaka Alfonsina K. opiewała bezgraniczne poświęcenie Sióstr Miłosierdzia, żyjących nie dla siebie, lecz dla nieszczęśliwych tego świata, pokornie spieszących z pomocą, czuwających nad konającymi, otaczających serdecznością sieroty ${ }^{24}$. Walentyna Trojanowska szczegółowo opisała czytelnikom dobroczynną działalność szarytek ze Zgromadzenia św. Wincentego a Paulo ${ }^{25}$. Mali odbiorcy zapoznać się mogli z żywotami świętych, choćby św. Jana Kantego ${ }^{26}$, św. Jadwigi Śląskiejej, św. Kingii28, również z historią życia Najświętszej Marii Panny ${ }^{29}$. Dzięki lekturze „Zorzy” dzieci otrzymywały zatem gotowe wzory do naśladowania, w myśl że każdy człowiek wezwany jest do świętości. Nagrodą za święty żywot było zaznawanie wiecznej szczęśliwości w niebie, tylko poprzez cnoty wiodła droga do zbawienia. Mylili się chłopcy, którym zdawało się, że po wysokiej drabinie dostaną się do nieba, Teofil Nowosielski wyprowadził ich z błędu -
"Jedna tylko jest drabinka
do gwiazdeczki złotej;
Po niej każdy się dostanie
Kto szedł tam przez cnoty"30.

Pisano dzieciom o nieśmiertelności duszy, szlachetne postępowanie, przestrzeganie przykazań Bożych gwarantować miało „błogą wieczność”" Przypominano, że ziemska egzystencja była tylko pewnym etapem, pielgrzymką do lepszego życia ${ }^{32}$. Posępny wątek śmierci od czasu do czasu pojawiał się na łamach czasopisma, próbowano oswoić dzieci z koniecznością umierania, pokazać śmierć nie jako koniec, ale jako początek. W opowiadaniu Anioł Stróż dzieci rozpaczały po śmierci trzynastomiesięcznej siostrzenicy Michasi - „zimnej, bladej i w głębi ziemi”, a matka pocieszała je, wyjaśniając, że dusza dziewczynki jest szczęśliwsza w niebie niż na ziemskim padole i że z pewnością uprosi u Pana Jezusa pokrzepienie dla pogrążonych $\mathrm{w}$ żałobie rodziców ${ }^{33}$. Podobnie dziadek

\footnotetext{
23 P. K., Strach, tamże, 1843, t. II, s. 135-138.

${ }^{24}$ Alfonsina K., Poklask i błogosławieństwo, tamże, 1843, t. II, s. 179-181.

25 W. T., Klasztor św. Kazimierza w Warszawie, tamże, 1843, t. I, s. 49-58.

26 P. K., Miłość prawdy, tamże, 1843, t. III, s. 166-168.

27 Taż, Wspomnienia kobiet wsławionych w Polsce: Święta Jadwiga, tamże, 1844, t. V, s. 65-71.

${ }_{28}$ Taż, Wspomnienia kobiet wsławionych w Polsce: Święta Kunegunda, tamże, s. 217-222.

29 Taż, Z historii Najświętszej Marji Panny, tamże, 1843, t. I, s. 131-138.

30 T. Nowosielski, Drabinka do nieba, tamże, 1844, t. VI, s. 93-94.

31 A z O. T., Anioł Stróż, tamże, s. 191-192.

32 P. K., O moralności, tamże, s. 223.

33 A z O. T., Anioł Stróż..., s. 191-192.
} 
z wiersza zapewniał wnuki, że pogodzony z losem odchodzi do innego świata, ale nawet stamtąd, choć niewidzialny dla ich oczu, roztaczać będzie nad nimi pieczę:

„Ja w ciemnym grobie przeżyję wieki,

Ciało, mogiła pokryje,

Lecz was nie puszczę jeszcze z opieki,

Póki ostatni dożyje" ${ }^{\prime 34}$.

Przezorny dziadek pozostawiał wnukom duchowy testament, dowodził, że śmierć ciała jest niczym wobec wieczności, toteż ostrzegał przed zatraceniem duszy:

„Jeśli niepomni na powołanie

Wy zapomnicie o Bogu,

Życie, goryczą wieczną się stanie,

Zginiecie na życia progu"35.

Ponieważ „Zorza” adresowana była także do najmłodszych, nie zaniedbywano potrzeby wyjaśnienia podstawowych prawd wiary. Przykładowo zabawny dialog „ciekawej” pięcioletniej Felci i jej mamy rozjaśniał nieco tajemnicę odkupienia. "-Któż też to nas kupił? [...] Bo kiedy nas Pan Jezus odkupił, to wprzódy ktoś inny kupił zapewne” - mama wytłumaczyła córeczce, „że my nie byliśmy przez nikogo sprzedani, tylko że utraciliśmy łaskę przez grzech pierwszych naszych rodziców: to jest Adama i Ewy, a Pan Jezus odkupił nas od tego grzechu swoim przyjściem na świat i swoją śmiercią"36. Jak widać, w „Zorzy” zachęcano dzieci do modlitwy, wzywano do czynienia dobra w imię Boże, a przy okazji zapoznawano z teoretycznymi zagadnieniami wiary chrześcijańskiej. Niekłamana, autentyczna pobożność, daleka od dewocji, oparta na zawierzeniu Bogu i czerpaniu sił z wiary, miała być fundamentem, na którym można było zbudować godne życie, zdrojem, z którego wypływałyby pozostałe cnoty.

\section{Zachwyt nad pięknem stworzenia}

Piękno stworzenia wyrastało na dobitny wyraz potęgi Stwórcy i Jego nieskończonej miłości. Dziękczynny zachwyt nad harmonią świata, w którym wszystko ma swoje miejsce, swój czas i wyznaczoną rolę do spełnienia, winien wyrywać się z dziecięcego serca:

„Pan Bóg wszystko stworzył

Dla pociechy ludzi,

34 Ks. H. P., Zgon dziadka, tamże, s. 229-231.

35 Tamże.

${ }^{36}$ J. Prusiecka, Ciekawa Felcia, tamże, 1843, t. III, s. 207-208. 
Niech się więc w serduszkach

Waszych wdzięczność budzi”37.

W wierszu Leontyny M. matka zachęcała córkę, aby ta wstała skoro świt i cieszyła się czarownym wiosennym porankiem. Dziewczynka radowała się widokiem kolorowego kwiecia, zapachem łąki, świergotem ptasząt:

„Tak gdzie tylko zwrócę oko,

Czy to nisko, czy wysoko,

Wszystko piętno Boga nosi,

Wszystko jego wielkość głosi”38.

W opowiadaniu Każdemu jest dobrze Józefa Prusiecka pouczała małych czytelników, że „Pan Bóg wszystkich stworzył do szczęścia i pamięta o wszystkim", toteż skowronek niepotrzebnie użalał się nad wiewiórką, że ta nie potrafi wzbić się w górę i szybować po niebie, wiewiórka na próżno żałowała zajączka biegającego po ziemi, niezdolnego wspi-

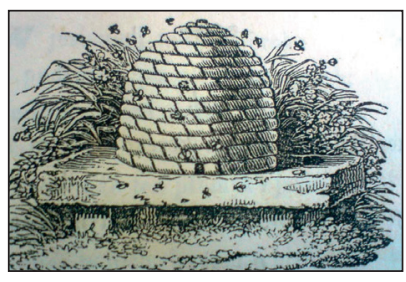
nać się po drzewach, to samo tyczyło się zajączka współczującego rybkom moknącym i marznącym w wodzie, rybki z kolei na darmo z politowaniem ubolewały nad losem ptaszków i zwierzątek, którym nie dane było ochłodzić się w wodnej toni ${ }^{39}$. Podziwianie fauny i flory, logiki i celowości ustanowionych w przyrodzie, powinno iść w parze z poszanowaniem, dbałością, z przemyślanym, ostrożnym obchodzeniem się ze światem natury. Urzeczona rozkoszami wiosennego poranka bohaterka wiersza Leontyny M. rozważała, jak najpełniej człowiek potrafi odwdzięczyć się Stwórcy za dar stworzenia:

„Drogie ołtarze, jałmużny, Kosztowne kościołom dary

Choćby złożył, jeszcze dłużny

Byłby jego wszechmocności"

i dowiedziała się od matki, że dla Boga najwspanialszą zapłatą jest:

„Byś darów jego szczodroty

Na złe nigdy nie użyła" ${ }^{\prime 0}$.

Ania z opowiadania Wszystko potrzebne na świecie litowała się nad biedronką i pod groźbą grzechu nie pozwoliła bratu zabić „bożej krówki”. Dziewczynka

37 S. Jachowicz, Wiersz bez tytułu, tamże, 1843, t. I, s. 285-286.

${ }^{38}$ Leontyna M., Rozmowa, tamże, s. 139-141.

39 J. Prusiecka, Każdemu jest dobrze, tamże, 1843, t. III, s. 199-200.

40 Leontyna M., Rozmowa..., s. 139-141. 
wpadła natomiast na pomysł, by zamiast biedronki brat unicestwił „szkaradnego pająka, co tam w kącie na biedne muszki sieci zastawia", ale i tu mama - pierwsza, najważniejsza wychowawczyni - skutecznie odwiodła ją od tego zamysłu, objaśniając, że i pozornie brzydki pająk jest pożytecznym stworzeniem, na równi z biedronką kochanym przez Boga, ponadto uświadomiła córce, że Stwórca zakazał człowiekowi niszczyć czegokolwiek bez potrzeby ${ }^{41}$.

Docenianie piękna stworzenia, umiar i rozsądek w czerpaniu korzyści ze świata, dopełniać powinna ciekawość świata, dążenie do pozyskania wiedzy i ciągłego jej pogłębiania. Dlatego też redakcja „Zorzy” troszczyła się o dobór artykułów budzących dziecięcą dociekliwość, chęć poznania i zrozumienia, stawiania pytań i szukania na nie odpowiedzi. Pismo podejmowało zróżnicowane zagadnienia - o słoniu ${ }^{42}$ i ptaku-muszce ${ }^{43}$, czyli kolibrze, pisała dzieciom Walentyna Trojanowska, Paulina Krakowowa sięgnęła po mniej egzotyczne, acz nie mniej interesujące tematy, opowiadając o żubrze ${ }^{44}$ bądź pszczole miodnej, przy czym nie zapomniała o morale - „bogdajbyśmy biorąc pszczółki za wzór do naśladowania starali się nawyknąć do pracy, zgody, miłości dla bliźnich, i tylu szacownych przymiotów, którymi je szczodra obdarzyła natura, a które my ludzie pracą tylko i usilnością nabyć możemy" ${ }^{\prime 5}$. Dzieci dowiedzieć się mogły także, czym są skamieniałości ${ }^{46}$, jaką drogę przebywa wstążka, zanim jako gotowy wyrób cieszący dziewczęce oczy zostanie wpleciona we włosy ${ }^{47}$, jak wygląda powitanie u królów plemion afrykańskich ${ }^{48}$ czy na czym polega taniec węży ${ }^{49}$. List Melusi do Felcia streszczający wrażenia $z$ wizyty $w$ teatrze lalek $z$ pewnością zachęcił niejednego czytelnika do odwiedzenia teatru ${ }^{50}$. Nie brakowało artykułów z zakresu historii sztuki, dzieci wyposażano w informacje dotyczące twórczości mistrzów pędzla i dłuta, wśród nich Wita Stwosza ${ }^{51}$ i Michała Anioła ${ }^{52}$. Wiedzy geograficznej, przyrodniczej i historycznej dostarczały Listy z podróży - zbiór listów publikowanych w dwóch pierwszych tomach „Zorzy”, adresowanych kolejno z Radomia, Miechowa, Krakowa, Ołomuńca i Pragi ${ }^{53}$, Wędrówka - listy Stanisława do siostry Zofii oddające piękno Karpat ${ }^{54}$, Wyciągi z dziennika podróży do wód mineralnych kaukazkich Ignacego Dobrskiego ${ }^{55}$. List z Częstochowy opisywał połączone z modlitewnym skupieniem

${ }^{41}$ P. K., Wszystko potrzebne na świecie, tamże, 1843, t. III, s. 188-190.

42 W. T., O słoniu, tamże, 1843, t. II, s. 191-197.

43 Taż, Ptak-muszka, tamże, 1843, t. IV, s. 143-145.

44 P. K., O żubrze, tamże, s. 206-210.

45 Taż, Pszczoła, tamże, 1844, t. VI, s. 243-252.

${ }^{46}$ Co to są skamieniałości, tamże, 1844, t. V, s. 269-281.

47 P. K., Wstążki, tamże, 1844, t. IV, s. 212-216.

48 Powitania u różnych narodów, tamże, 1843, t. II, s. 88-89.

49 W. T., Taniec wężów, tamże, 1843, t. I, s. 188-190.

50 Taż, O marionetkach, tamże, 1843, t. IV, s. 247-250.

51 J. W., Wit Stoss krakowianin snycerz wieku piętnastego, tamże, s. 1-4.

52 P. K., Michał Anioł Buonarotti, tamże, 1843, t. III, s. 75-90.

${ }^{53}$ W. T., Listy z podróży, tamże, 1843, t. I, s. 146-158, 221-227, 273-282; t. II, s. 55-63, 105107, 198-213.

${ }^{54}$ P. K., Wędrówka, tamże, 1843, t. I, s. 2-20.

55 I. Dobrski, Wyciągi z dziennika podróży do wód mineralnych kaukazkich, tamże, 1843, t. III, s. $43-50,148-154,218-225$. 
zwiedzanie klasztoru na Jasnej Górze ${ }^{56}$, prenumeratorzy pisma zaznajomili się też z zarysem dziejów Lwowa ${ }^{57}$. Czytelnikom nieobca była znajomość jednostek nominalnych pieniądza w dawnej Polsce ${ }^{58}$. Periodyk zapoznawał swoich adresatów z narodową historią, obyczajami i tradycją. W dobie utraty niepodległości wskrzeszał panteon bohaterów z odległej historii, z czasów świetności państwa polskiego. Podajmy kilka przykładów. W przystępny sposób w Rozmowie dziadunia o Jerzym Ossolińskim - Walentyna Trojanowska przywołała osobę kanclerza wielkiego koronnego Jerzego Ossolińskiego ${ }^{59}$. W opowiadaniu Konik dzieci mogły przeczytać o Stefanie Czarnieckim ${ }^{60}$. Ciekawa musiała być lektura fragmentów korespondencji Barbary Radziwiłłówny, Anny Jagiellonki, Izabelli Jagiellonki i Katarzyny z Opalińskich Leszczyńskiej ${ }^{61}$. Paulina Krakowowa w cyklu Wspomnienia kobiet wsławionych w Polsce przybliżyła postać małżonki Mieszka I - Dąbrówki, Bolesława Chrobrego - Judyty, Mieszka II Lamberta - Rychezy, wiernej żony rycerza Bolesława Śmiałego - Mikołaja - Małgorzaty z Żębocina, żony Henryka Brodatego - Jadwigi Śląskiej, Kazimierza Sprawiedliwego - Heleny i Bolesława Wstydliwego - Kingi ${ }^{62}$. Ponadto adekwatnie do pory roku przyglądano się: zimą zwyczajowi ${ }^{63}$ chodzenia po domach z szopkami bożonarodzeniowymi ${ }^{64}$, wiosną zwyczajowi święcenia wianków podczas uroczystości Bożego Ciała ${ }^{65}$.

Lektura „Zorzy” dostarczała dzieciom wiadomości o świecie, uzupełniała ich dotychczasowy zasób wiedzy, pozwalała przyswoić nowe treści, przypomnieć już kiedyś zasłyszane, zapoznać się z ciekawostkami. Pismo pełniło rolę pomocniczą w stosunku do lekcji pobieranych u zatrudnionych w domu guwernantek i metrów. O ile „Zorzę” z pewnością czytało się dzieciom lekko i przyjemnie, o tyle podręczniko-

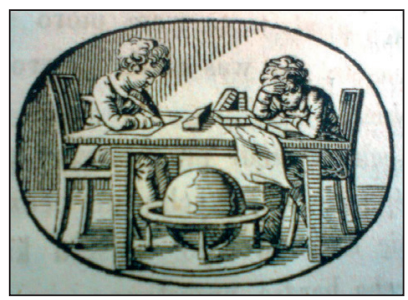
wa edukacja nieraz wiązała się ze stresem, mozołem, zmęczeniem. W niełatwym procesie nauczania niezbędne stawały się pracowitość, pilność, obowiązkowość, sumienność, dokładność, a przede wszystkim cierpliwość. I te cechy kształtowała w małych czytelnikach uważna lektura periodyku. Już pierwszy tom umyślnie otwierał wiersz Walentyny Trojanowskiej w tytule mający „zorzę" - słowo-klucz. Zorza jaśniejąca na niebie różowym blaskiem zwiastuje nastanie nowego dnia, a wraz z nim nowych nadziei. Pojawia się tuż przed wschodem słońca, zanim to rozbłyśnie na niebie w pełni majestatu. Trojanowska zwróciła się do dzieci:

\footnotetext{
56 J. J., List z Częstochowy, tamże, s. 112-117.

57 P. K., Z dziejów miasta Lwowa, tamże, s. 171-188.

58 W. T., O monetach dawnych polskich, tamże, 1843, t. I, s. 44-46.

59 Taż, Rozmowa z dziaduniem o Jerzym Ossolińskim, tamże, 1843, t. II, s. 156-165.

60 L. W., Konik, tamże, 1844, t. V, s. 58-60.

61 Wyjątki z listów czterech królowych, tamże, s. 253-258.

62 P. K., Wspomnienia kobiet wsławionych w Polsce: Dąbrówka, tamże, 1843, t. II, s. 24-40;
} Judyta, t. IV, s. 147-150; Ryxa, t. IV, s. 219-226; Małgorzata z Zembocina, t. V, s. 1-6; Święta Jadwiga, t. V, s. 65-71; Helena, t. V, s. 121-122; Święta Kunegunda, t. V, s. 217-222.

63 O znaczeniu zwyczajów i obrzędów zob.: J. W. S., Estetyczność zwyczajów i obrzędów, tamże, 1843, t. II, s. 171-173.

64 P. K., Szopki, tamże, 1844, t. V, s. 54-57.

65 W. T., Wianki. Obrazek wiejski, tamże, 1843, t. I, s. 98-104. 
„Spojrzyjcie w zorzę - a oczęta drobne

Nie olśni jaskrawe słońce"66

i w tym wezwaniu należałoby odczytać pewien głębszy sens - tak jak patrząc wprost w słońce, dzieci doznałyby chwilowego oślepienia, tak chcąc od razu spełnić marzenia, zrealizować upragnione cele, nie zdołałyby osiągnąć niczego. Bez włożenia wysiłku, bez osobistego zaangażowania i wytężonej pracy próżno spodziewać się efektów, trzeba krok po kroku piąć się do celu, zapatrzeć się w zorzę, a nie w słońce.

„Wstańcie dziateczki! aby żyć i użyć

Budzić się trzeba o świcie;

Pełnym uczuciem światu się wysłużyć,

Zrozumieć życie, - to życie!"ø7.

Władysław Miniewski w bajce Krówka i pszczoła wtórował:

„Młodzieży! pókiś w pięknych życia latach,

Niechaj i w tobie chęć pracy nie drzemie;

Jak pszczółka, igraj po kwiatach,

Jak pszczółka, pomnij o zimie"68.

Wszystko powinno mieć swój czas - swawole, uciechy, przyjemności, a obok nich praca na miarę sił, przy czym nierzadko zdarzyć się mogło, jak miało to miejsce właśnie w przypadku „Zorzy. Dziennika młodemu wiekowi poświęconemu”, że udawało się przyjemne połączyć z pożytecznym.

\section{„Kochajcie dzieci skromność i prostotę"}

Autorom współpracującym z „Zorzą" skromność i prostota wydawały się być nieodłącznym atrybutem dobrego dziecka, a zarazem czymś naturalnym, stosownym dzieciństwu, darem, którego dziecku nie wolno było w sobie zatracić. Stanisław Jachowicz w wierszu Do dzieci polecał młodym czytelnikom:

„Kochajcie dzieci skromność i prostotę, Wśpiewujcie sobie do serduszka cnotę, Krzepcie się piosnką, jak rosą kwiateczki, bądźcie pociechą ojca i mateczki!"69.

66 Taż, Zorza, tamże, s. 1.

67 Tamże.

68 W. Miniewski, Bajka. Krówka i pszczoła, tamże, s. 183-184.

69 S. Jachowicz, Do dzieci, tamże, 1844, t. V, s. 259. 
Brak skromności - zarozumiałość, zuchwałość, pycha pociągały za sobą pogardę, zazdrość, zawiść, niechęć wobec drugiego człowieka. Mozaika tych amoralnych postaw i odczuć nie przystawała dziecku. „Piątaczek” z wiersza Jachowicza, chciwy matczynej miłości, nie chciał się nią dzielić z czwórką przybranego rodzeństwa i hardo uważał się za jedynaka, zajmującego w sercu matki bezsprzecznie pierwsze miejsce. Dopiero napomnienie rodzicielki - „czworo przed tobą", „a tyś dopiero piątaczek” - sprowadziło nieskromnego syna na ziemię, nauczyło pokory i utwierdziło w miłości do sióstr i braci ${ }^{70}$. W opowiadaniu Dwie przyjaciółki Klara pochodząca z zamożnej kupieckiej rodziny wstydziła się swojej dawnej najlepszej przyjaciółki z pensji - Marii, próżna panienka obawiała się kompromitacji przed nowymi koleżankami z powodu skromnego ubioru Marii, której ojciec ubogi adwokat nie był w stanie zapewnić strojnych sukien. Bogactwo przesłoniło Klarze wagę przyjaźni, by wkupić się do grona nowo zapoznanych, dobrze sytuowanych znajomych, wyrzekła się przywiązania do niegdyś uwielbianej Marii, wzgardziła jej sympatią. Zmienność losu sprawiła, że nieoczekiwanie ojciec Klary utracił cały majątek i umarł ze zgryzoty, w tym samym czasie ojciec Marii odziedziczył fortunę. Nowe koleżanki odwróciły się od Klary, dopiero wtedy ta pojęła, jak wielką krzywdę wyrządziła kiedyś Marii, bolała nad utraconą przyjaźnią i swoje nieszczęsne położenie znosiła jako zasłużoną karę. Cała historia znalazła szczęśliwe zakończenie, ponieważ wielkoduszna Maria przebaczyła skruszonej przyjaciółce i wyprosiła rodziców, by przyjęli tę do domu jako drugą córkę $^{71}$. W „Zorzy” powtarzano dzieciom, że wyznacznikiem wartości człowieka nie jest jego stan posiadania, pozycja zajmowana w społecznej hierarchii, ani też uroda podlegająca prawom przemijania - bogactw należy szukać w sobie, a nie wokół siebie. „Jeżeli zwierciadło ci pochlebi, wspomnij że piękne ciało winno być lepianką tym piękniejszej duszy"72. W Prawdziwym pięknie mądry brat pouczał młodszą siostrzyczkę:

„W ogrodzie świata, droga Ludmilko!

Obaczysz dużo motyli,

Ale na piękność duszy patrz tylko,

Ta jedna tylko nie myli!!”3.

Dzieci mające do swoich usług wynajętych pracowników winny uszanować ich pracę, wydawanie rozkazów zastąpić grzeczną prośbą, a już pod żadnym pozorem nie powinny traktować ich z góry. Zaskakujący spokój i humor służącego wywarły zbawienny wpływ na porywczego Marcinka. Chłopiec łatwo popadał w irytację i raz rozgniewawszy się na sługę, pogardzając nim jako swym podwładnym, nieomal nie uderzyłby go w twarz, gdyby nie nieprzewidziana reakcja sługi:

\footnotetext{
70 Tenże, Piątaczek, tamże, 1843, t. I, s. 29-30.

71 P. K., Dwie przyjaciółki, tamże, 1843, t. II, s. 3-17.

72 M. Z., Użytek moralny zwierciadła, tamże, 1843, t. IV, s. 74-75.

73 K. B., Prawdziwa piękność, tamże, 1844, t. VI, s. 138-142.
} 
„Uderzyć chcesz mnie widzę szczerze,

Ale cóż, nie dostaniesz! - ot ja ci poradzę:

Poproś mnie panicz pięknie, to ja cię podsadzę"74.

Zdumiony Marcinek stał się świadkiem ewangelicznego nadstawiania policzka, żywiony gniew ustąpił, a jego miejsce zajęły wstyd i szczera skrucha.

„I postanowił w duszy, że na przyszłość będzie

Wrodzoną popędliwość miarkować w zapędzie.

Długo, długo z nią walczył zanim przemóc zdołał,

Ale że walczył stale, Boga w pomoc wołał,

Bóg mu pobłogosławił"75.

„Zorza” uprzytamniała dzieciom, że w pokonywaniu własnych słabości, przezwyciężaniu złych skłonności z pomocą przychodził Bóg, a zaraz po Bogu podpory należało szukać u rodziców i nauczycieli. Stąd szacunek przynależny matce i ojcu, traktowanie z estymą ludzi starszych, dziadków, krewnych, piastunek, pedagogów. Leontyna M. przypominała dziecinie o zaufaniu, posłuszeństwie i stałej potrzebie okazywania rodzicom i wychowawcom wdzięczności, dawania dowodów miłości i przywiązania:

„Czcij Matkę, Nauczycieli.

Gdy ci pierwsza życie dała,

Drudzy żyć cię nauczyli;

Twoja największa w tym chwała

Być im wdzięczną w każdej chwili" ${ }^{\prime 6}$.

Rodzice spieszyli nie tylko ze wsparciem, ale i służyli dobrym przykładem, toteż dzieci w swoim zachowaniu powinny wzorować się na postępowaniu matki i ojca. Autorzy publikujący w „Zorzy” zakładali rzecz jasna, że rodzice żyli w zgodzie z moralnością i dokonywali tylko dobrych wyborów. Paulina Krakowowa wskazywała na ogrom odpowiedzialności spoczywającej na rodzicach i opiekunach, bowiem to im w udziale przypadała doniosła rola pierwszych przewodników dzieci w ziemskiej podróży, to oni „wpajają w pamięć nauki i przestrogi jak się chronić upadku, a nawet potknięcia [...] i idąc za ich głosem możemy być pewni niezbłądzenia"77. Szymon Zajączkowski w bajce Orzeł i orlęta przyrównał małych czytelników do orląt, które uczyły się latać poprzez naśladowanie orła, same nie potrafiły oderwać się od ziemi, dopiero gdy zapatrzyły się w ojca, poszybowały za nim wysoko w obłoki. Analogicznie dzieci pozbawione rodzicielskiego

\footnotetext{
${ }_{74}^{74}$ M. Ossorja, Marcinek, tamże, s. 47-48.

75 Tamże.

76 Leontyna M., Rozmowa..., s. 139-141; Miłość należna była również macosze - o Henryku, który przekonał się do drugiej matki, dzieci przeczytać mogły w Powiastce - M. B., Powiastka, tamże,

77 P. K., O moralności, tamże, 1844, t. VI, s. 223-225.
} 1843 , t. III, s. 27-35. 
przewodnictwa $z$ góry skazane były w życiu na niepowodzenie. Tylko czerpiąc $z$ doświadczenia starszych, z rodzinnej tradycji mogły wyrosnąć na szlachetnych ludzi. Zatem Zajączkowski apelował:

„I ty dziecino! już zmłodu

Idź za tych orląt przykładem;

Weź cnotę za cel twojego zawodu,

I dąż do góry za ojcem, za dziadem"78.

\section{Miłość bliźniego}

„Zorza” wzywała dzieci do wypełniania trojakiego rodzaju obowiązków: wobec Boga, wobec siebie samych poprzez niezaniedbywanie nauki, doskonalenie swojej wiedzy, i wreszcie wobec bliźnich ${ }^{79}$. Pod pojęciem bliźnich dzieci rozumieć miały nie tylko ludzi im życzliwych - rodziców, krewnych, pedagogów, bliźnimi byli także nieraz mniej lubiani koledzy i koleżanki, zatrudnieni w domu służący, czy sąsiedzi dworu - włościanie. Najważniejsze Chrystusowe przykazanie wyraźnie napominało: „Kochaj bliźniego swego jak siebie samego”, dlatego redaktorki pisma zwracały uwagę czytelników na potrzebę wytworzenia braterskiej relacji z drugim człowiekiem, uczyły uprzejmości, pokazywały, jak wiele w codzienności znaczy promienny uśmiech, dobre słowo, a przede wszystkim ofiarny czyn, w powiastkach z morałem udowadniały, że okazana dobroć wraca do dobroczyńcy w dwójnasób. Uosobieniem oddanego przyjaciela dla niejednego czytelnika stał się Staś z opowiadania Wincentyny T., który pragnął jak najpiękniej uczcić imieniny swojej rówieśniczki Zosi i z przejęciem rozważał, jaki prezent sprawiłby dziewczynce największą radość ${ }^{80}$. Maria - główna bohaterka powieści Pauliny Krakowowej Wspomnienia wygnanki, publikowanej w odcinkach na łamach „Zorzy" - całym swoim życiem realizowała biblijne wyobrażenie miłości bliźniego. W każdym człowieku napotkanym na swojej drodze potrafiła dostrzec Boga, bezinteresowna i dobroduszna emanowała altruizmem ${ }^{81}$. Dążenie do uszczęśliwiania innych stawać się miało źródłem spokoju sumienia i niezmąconej satysfakcji. Tym większe zadowolenie płynęło z czynienia dobra, im bardziej potrzebujących nim obdarowywano. Piętnastoletnia panienka Anilora K. wyrażała ciągłą gotowość wspierania wyglądających otuchy:

„Bo to nigdy być nie może

Bym nie starła łzy biednego,

\footnotetext{
${ }^{78}$ Sz. Zajączkowski, Orzeł i orlęta, tamże, 1843, t. I, s. 181-182.

79 P. K., O moralności..., s. 225.

80 W. T., Imieniny Zosi, tamże, 1844, t. VI, s. 113-120.

81 P. K., Wspomnienia wygnanki, tamże, 1844, t. V, s. 10-34, 92-107, 137-146, 181-201, 222
} 252, 289-304; t. VI, s. 23-33, 69-85, 120-138, 162-185. 
Tyś sam kazał, wielki Boże!

Kochać Ciebie i bliźniego"82.

Chłopczyk z wiersza Jałmużna podzielił się posiłkiem z wygłodzonym ułomnym staruszkiem ${ }^{83}$, panienka z opowiadania Biedny Góral wsparła datkiem wynędzniałego węgierskiego druciarza ${ }^{84}$. Można by mnożyć podobne przykłady. Poza egzemplifikacjami wymyślonymi dla potrzeb dydaktycznych zapoznawano dzieci z rzeczywistą działalnością instytucji dobroczynnych, choćby Paulina Krakowowa pochwalała podjętą przez Warszawskie Towarzystwo Dobroczynności inicjatywę wydawania ubogim zupy rumfordzkiej ${ }^{35}$, osobny artykuł poświęciła też nowo założonemu Instytutowi Ociemniałych w Warszawie $^{86}$. Na łamach „Zorzy” szczególnie uwrażliwiano czytelników na problemy, z jakimi zmagała się ludność chłopska i biedota miejska: praca w po-

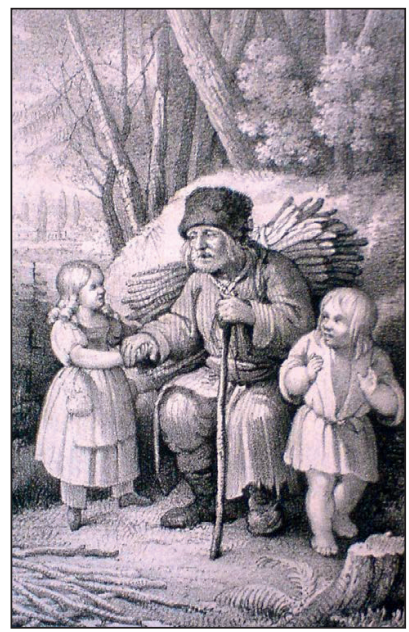
cie czoła, głód i ubóstwo, kształtowano w dzieciach zdolność empatii, rozpalano w sercach i umysłach pragnienie ulżenia ciężkiej wieśniaczej czy robotniczej doli87. Uświadamiano przy tym czytelnikom, że samo współczucie nie wystarczało, litość nieprzynosząca owoców była bezwartościowa. Żal należało przełożyć na konkretne uczynki miłosierdzia. Panienka z dworku Lina była tytułowym „Aniołkiem bez skrzydeł”, usłużnie wspomagała okolicznych włościan, zyskując w zamian wyrazy wdzięczności i błogosławieństwo ${ }^{88}$. Czytelnicy „Zorzy” również mogli zasłużyć sobie na chlubne miano ziemskich aniołków. Wystarczyło nakarmić głodnego, zasilić kieszonkowym potrzebującego, uszyć koszulkę dla biednej sieroty, czapeczkę dla sędziwej niewiasty ${ }^{89}$, doglądać ochronki ${ }^{90}$, czy przy udziale dorosłych zorganizować teatrzyk, zabawę taneczną bądź loterię fantową, a płynący z nich dochód przeznaczyć na cele filantropijne ${ }^{91}$. Przy okazji przestrzegano dzieci, aby akty miłosierdzia wypływały z miłości chrześcijańskiej i społecznego solidaryzmu, by nie miały niczego wspólnego z dobroczynnością na pokaz, dla uzyskania pochwały u ludzi ${ }^{92}$.

82 Anilora K., Co ja lubię, tamże, 1843, t. II, s. 254-255.

${ }^{83}$ H. P, Jałmużna, tamże, 1843, t. I, s. 179-180.

84 W. T., Biedny Góral, tamże, s. 93-94.

85 P. K., Obiad pięciogroszowy, tamże, 1843, t. II, s. 139-148.

86 Taż, Kilka słów o Instytucie Ociemniałych w Warszawie, tamże, 1843, t. IV, s. 227-232.

87 J. F., Myśli o gminie, tamże, 1843, t. II, s. 243-250.

88 P. K., Aniołek bez skrzydet, tamże 1843, t. I, s. 21-28.

89 W. T., O robótkach kobiecych, tamże, 1843, t. III, s. 35-40.

90 Taż, List młodej ziemianki, tamże, 1843, t. I, s. 105-113.; taż, Drugi list młodej ziemianki, tamże, 1844, t. V, s. 71-80.

91 P. K., Rozmaitości..., s. 237-238.

92 Ks. P. Rzewuski, Dobroczynność światowa i dobroczynność religijna, „Zorza” 1844, t. VI, s. 233-236. 


\section{Miłość ojczyzny}

Polskie dziecko winno być wychowywane w duchu patriotyzmu, poszanowania tradycji, ojczystego języka i kultury. Doskonale rozumiały to redaktorki „Zorzy” i niewątpliwie wychowaniu patriotycznemu służyły scharakteryzowane wcześniej treści historyczne publikowane na łamach pisma. Tematów z najnowszej historii $z$ uwagi na cenzurę nie wolno było podejmować, pozostawał za to bogaty materiał w postaci wypadków z zamierzchłych, chwalebnych dziejów narodu. Cytowana już Anilora K. w przysłanym do redakcji utworze lirycznym Co ja lubię w pierwszej strofie deklarowała:

„Co ja lubię? ojców ziemię,

Własną mowę, własne plemię,

Nasze pienia i te śpiewy

Które nuci kmieć poczciwy"93.

Komedię Powrót wuja wymierzono przeciw modzie na francuszczyznę - jej bohaterka Marynia przedkładała nad własny język znajomość francuskiego, uczyła się na pamięć francuskiej poezji, grała na fortepianie francuskie uwertury, w codziennej mowie mieszała ojczyste zwroty z obcymi, szczęśliwie wuj-patriota położył kres modnemu wychowaniu siostrzenicy, nauczył ją szacunku do polskości ${ }^{94}$. O dziejach języka polskiego i literatury polskiej opowiadał obszerny artykuł O czytaniu autorów polskich, wśród pisarzy, którymi chlubił się polski naród, wymieniając ojców narodowej literatury: Mikołaja Reja, Jana i Piotra Kochanowskich, Marcina Bielskiego, Szymona Szymonowica, Sebastiana Fabiana Klonowica, Szymona Zimorowica, Łukasza Górnickiego, Piotra Skargę i Stanisława Grochowskiego, pośród wybitnych klasyków: Adama Naruszewicza, Ignacego Krasickiego, Stanisława Trembeckiego, Franciszka Dionizego Kniaźnina, Franciszka Karpińskiego, oraz romantyków: Kazimierza Brodzińskiego, Adama Mickiewicza, Seweryna Goszczyńskiego, Józefa Korzeniowskiego, Józefa Ignacego Kraszewskiego ${ }^{95}$.

Za pośrednictwem języka ezopowego dyskretnie wyrażano nieutuloną tęsknotę za utraconą niepodległością, nadzieję na lepsze jutro, na odzyskanie wolności - wiersz Do jaskółki kończyło znaczące westchnienie:

"O jak to miło, ptaszyno moja,

Mieć zagrodę własną;

Chociażby małą, chociażby ciasną,

Byle tylko była swoja" 96 .

${ }_{93}$ Anilora K., Co ja lubię..., s. 254-255.

94 Henryka K., Powrót wuja, „Zorza” 1843, t. II, s. 108-123.

${ }_{95}$ A. Z., O czytaniu autorów polskich, tamże, 1843, t. IV, s. 150-163.

96 Marya M., Do jaskółki, tamże, 1843, t. I, s. 31-32. 
Wiele wymagano od młodego pokolenia, wiązano z nim wielkie nadzieje, to wszakże dzieci uchodziły za zorzę narodu. I znów zorza kryła w sobie symbolikę - wartości ukształtowane w dzieciństwie i wczesnej młodości, wypracowane zalety umysłu i charakteru, wyniesiony z domu patriotyzm procentowały w przyszłości:

„Tak dziatki, wyście zorzą narodu -

Lecz wiedźcie: chyżo czas leci;

Kto ranną zorzę prześpi za młodu

Ten nigdy słońcem nie świeci”’7.

Garstki ziemi - nieudawana religijność, szacunek dla dzieła stworzenia, skromność, pilność w zdobywaniu wiedzy, odpłacanie dobrem rodzicom i wychowawcom, miłość bliźniego i ojczyzny razem wzięte wznosiły się w górę moralnej dojrzałości. Krąg ludzi odpowiedzialnych za wychodzenie „Zorzy” wziął na siebie odpowiedzialność za włączenie się obok opiekunów i nauczycieli w moralne wychowanie dzieci i dorastającej młodzieży. Owe "garstki ziemi” służyły za drogowskazy, przekonywano, że od poszczególnych cnót, drobnych prawych uczynków prowadziła droga do prawdziwej moralności. Redaktorzy, wydawca, autorzy artykułów i wierszy przychylność serc młodych czytelników uznawali za najbardziej miarodajną nagrodę.

97 I. Dobrski, Zorza, tamże, 1843, t. IV, s. 145-146. 